\title{
Advanced techniques using the plant as indicator of irrigation management
}

\author{
Técnicas avançadas utilizando a planta como indicadora do manejo de irrigação
}

\author{
Barbara dos Santos Esteves ${ }^{I^{*}}$ Lidiane de Lima Lousada ${ }^{\mathrm{I}}$ \\ Elias Fernandes de Sousa ${ }^{\mathrm{II}}$ Eliemar Campostrini ${ }^{\mathrm{III}}$
}

\section{- REVIEW -}

\section{ABSTRACT}

The methodologies which are considered the most promising for irrigation management are those based on the analysis of the water status of the plants themselves. This justifies the study and improvement of indicators based on automatic and continuous measures to enable real-time monitoring data, as indices from sap flow, dendrometry and leaf turgor pressure techniques. The aim of this paper is to analyze such methodologies in order to demonstrate their principles, advantages and challenges. In conclusion, the methodologies analyzed still have many technological advances and challenges before being presented to the final user. The future research should work these tools for elaboration of technical indexes that allow their simplification, on the instrumental point of view, and the interpretation of their results.

Key words: sap flow, dendrometry, leaf turgor pressure.

RESUMO

As metodologias que se apresentam como as mais promissoras para o manejo de irrigação são aquelas baseadas na análise do status hídrico das próprias plantas. Isso justifica este estudo e o aprimoramento de indicadores baseados em medidas automáticas e contínuas que permitam acompanhamento em tempo real dos dados, como os índices provindos das técnicas do fluxo de seiva, dendrometria e da pressão de turgescência foliar. Nesse sentido, esta revisão se propõem a analisar tais metodologias de maneira a demonstrar seus princípios, vantagens e desafios. Como conclusão, tem-se que as metodologias analisadas ainda têm diversos desafios tecnológicos para serem apresentadas de maneira satisfatória ao usuário final. As pesquisas devem trabalhar estas ferramentas para elaboração de indices técnicos que permitam sua simplificação, tanto do ponto de vista instrumental, quanto para a interpretação dos seus resultados.
Palavras-chave: fluxo de seiva, dendrometria, pressão de turgescência foliar.

\section{INTRODUCTION}

Irrigation scheduling is often carried out based on soil water balance, in which evapotranspiration is estimated by using reference evapotranspiration and crop coefficient, according to the procedure proposed by FAO (ALLEN et al., 1998). This protocol, despite being widely spread, presents some uncertainty, especially when it comes to cultivation of isolated plants. In the case that the irrigated plant is considered in isolation, such as in an orchard, for example, the biggest problem is to determine the volume of water to be applied (ROJAS and ANGELOCCI, 2000) for each time period and the moment it should be applied. This is due to the little knowledge about the amount of water used by a plant during its transpiration with the soil in excellent water conditions (ROJAS and ANGELOCCI, 2000).

There are some techniques to determine water consumption by an individual plant. In the search for a rational irrigation management, new techniques to detect water deficiency in plants are being developed (SOUZA, 2009). The most promising methodologies are those based on the plant itself because they were more efficient than

IPrograma de Pós-raduação em Produção Vegetal, Centro de Ciências e Tecnologias Agropecuárias (CCTA), Universidade Estadual do Norte Fluminense Darcy Ribeiro (UENF), Av. Alberto Lamego, 2000, 28013-602, Campos dos Goytacazes, RJ, Brasil. E-mail: barbbarase@gmail.com.*Corresponding author.

ILLaboratório de Engenharia Agrícola, CCTA, UENF, Campos dos Goytacazes, RJ, Brasil.

IILLaboratório de Melhoramento Genético Vegetal, CCTA, UENF, Campos dos Goytacazes, RJ, Brasil. Received 04.03.14 Approved 09.18.14 Returned by the author 12.23.15 CR-2014-0501.R1 
the techniques that utilize environmental factors on water deficit indication (REMORINI \& MASSAI, 2003). Plant indicators have been used, primarily in research, as methods for estimating water stress; and their practical applications in irrigation management are still being developed (NAOR and COHEN, 2003).

Plant indicators that are traditionally used for irrigation scheduling that can be mentioned are: branch growth, leaf and stem water potential, and stomatal conductance (GOLDHAMER et al., 1999; REMORINI \& MASSAI, 2003; NAOR, 2006). These methodologies present limitations for irrigation schedule, highlighting the use of measures that cannot be automated because they result from labor-intensive and discontinuous processes.

This justifies the study and improvement of indicators based on automatic and continuous measures, to allow real-time monitoring of data. Among these new indicators, we can highlight measures based on sap flow, on trunk diameter variation and on leaf turgor potential. In this context, this review proposes to examine these automated indicators methods, demonstrating their advantages and challenges.

\section{Sap flow: different methodologies}

Most of the studies on transpiration of plants is based on methodologies of heat supply to the stem (BURGUESS \& DAWSON, 2008; ČERMÁRK et al., 2004), which presupposes the equivalence between the xylematic flow and leaf transpiration flow, in daily scale. SILVA (2008) reported that there are various techniques for obtaining sap flow and they can be separated into three groups. The first is the heat pulse method, which tracks the movement of a short heat pulse in the sap flow; the second is the heat balance method, which measures the sap movement, by heat transport, out of a controlled heat source; and the third method is the thermal dissipation, which reports the heat dissipation by sap flow through an empirical relation.

FERNÁNDEZ et al. (2001) examined the robustness of sap flow technique by heat pulse method, and it was considered, by the authors, suitable for estimating the dynamics of transpiration changes in the water behavior of trees. SANTOS et al. (2005) tested the heat pulse method for grapevine and concluded that the method can be used satisfactorily with instrumentation based on low-diameter and low heat supply sensors to mark sap flow.

Heat balance technique consists of applying heat around the circumference of the stem by a heat source. The mass flow of sap is obtained through the balance of the heat flows into and out of the heated section of the stem (SILVA, 2008). The heat balance method stands out in front of the other techniques for being an absolute and non-invasive method that requires no calibration procedures and involves relatively simple equipment, being the construction of sensors relatively easy and inexpensive (MARIN et al., 2008). However, the same authors ponder that, although easy handling and installation, there is a need for evaluation of measures quality for obtaining accurate data, and this practice is hard to be made, mainly in field conditions and in large plants.

GRANIER (1985) proposed the thermal dissipation method which allows one to determine the amount of water used by each plant for a certain period of time, through a xylematic flow monitoring. Assuming that most of the water carried through xylem is used in transpiration, it is possible to quantify, indirectly, the total amount of water transpired by the plant. The thermal dissipation method for measuring the xylematic Sap flow consists of a probe made up of two stainless steel cannulas inserted into the plant stem, with 3-cm length and 2-mm diameter, lined up vertically at a distance of approximately five inches. The use of the method of GRANIER (1985) has been observed in several studies and cultures (PIMENTEL et al., 2010; ROJAS et al., 2006).

\section{Water consumption from sap flow data}

According to RAMOS \& SANTOS (2009), the estimation of orchard water consumption, based on SAP flow measures or on any other methods, in individual trees, requires the expansion of data. These authors studied the relation between transpiration data obtained through the sap flow and water levels in the soil, obtaining water stress indices. LURBE (2013) cites that the use of sap flow methods is particularly suitable for studies on water deficit because this methodology may help to quantify both transpiration reduction and water stress level reached by the plant. FERNÁNDEZ et al. (2007) mention that the relative transpiration, obtained from the relation between tree sap flow in water deficit and well irrigated trees, has been discussed during the latest decades as an indicator of water stress. These authors have assessed the potential of sap flow measures for the use of high frequency irrigation management in vine and other fruit trees. They found that the method of relative transpiration was a good indicator of the right moment for irrigation. However, these authors stated that the use of this type of approach in a commercial orchard may not be practical due to problems associated with irrigation management, as for example, the excessive vegetative growth of plants used as reference. 
ORTUÑO et al. (2006) analyzed water stress detection in lemon, and they found that sap flow rates decreased progressively with reduced levels of water in the stressed plants. However, after rehydration, the sap flow values increased, getting close to the flow values of non-stressed plants. PONS et al. (2008) found that the sap flow measured in the evening is a good indicator of plant water condition in vines and it correlates very well with the stomatal conductance, and can be successfully used for irrigation management. FERNÁNDEZ et al. (2008a) declare that sap flow measures can be used for determining in situ water consumption of plants, and these systems are easily automated, obtaining satisfactory results to estimate transpiration.

FERNÁNDEZ et al. (2008b) developed and tested an irrigation automatic control system for fruit tree orchards. This device calculates water demand from sap flow readings in the trunk of the trees at the end of each day. The authors found that the system was capable of filtering and amplifying tensions of heat-pulse velocity probes to calculate sap flow data, obtaining the daily amount of irrigation water for orchards according to a specific protocol for the culture.

However, for SILVA (2008), sap flow measure in the field for purposes of irrigation management, with the existing equipment on the market, is a methodology that still has technological challenges to overcome, due to its high cost and sophistication. The same author studied the use of sap flow as an indicator of water stress in coffee and the elaboration of a simplified sensor model. With this research, the author concluded that the results obtained from the relation between sap flow and evapotranspiration indicated that this method can be employed as a tool to estimate the transpiration of coffee tree.

Use of dendometry in order to obtain crop water status

Dendrometry is based on the monitoring of changes in dimensions of plant organs in response to their water balance, and the use of the trunk or branches variations is more common. There are several works that mention this technique as promising for he irrigation management (PUERTO et al., 2013; ORTUÑO et al., 2010; ORTUÑO et al., 2006).The use of a very sensitive apparatus is necessary, once the variation in trunk diameter is very small (SOUZA, 2009). These devices are called dendrometers. They use fixed strain transducers on a steel arm, in which the smallest fraction of arm movement can be detected in the form of electrical signals that are subsequently converted to micrometrics signals.
The usefulness of different parameters derived from the continuous measurements of the trunk and the main branch was analyzed by GOLDHAMER \& FERERES (2001), who suggested that these measurements could be used as a valid technique for water stress detection in peach and almond, indicating that data may be considered for the establishment of precise irrigation schedules. The most commonly used parameters in the use of this technique are maximum daily diameter amplitude of trunk, stem and branches, and the variation of maximum or minimum daily diameter over the time (GOLDHAMER et al., 1999; GOLDHAMER \& FERERES, 2001).

ORTUÑO et al. (2006) found that the maximum trunk contraction is a suitable indicator for irrigation management in adult lemon trees. These authors stated that the possibility of developing reference or basal relations between maximum trunk contraction and reference evapotranspiration, allows the comparison between measurements of indicators based on plants at a given time and the expected value under water-limiting conditions, which can be calculated from the references.

FERNÁNDEZ et al. (2011a) analyzed the use of maximum trunk contraction measurements to detect water stress in olive trees under deficit irrigation. These authors found that these measurements are a useful index to detect the occurrence and severity of water stress in olive trees with high production. In this work it has also been suggested that the technique may be used as a strategy for programming lowfrequency irrigation, with deficit.

PÁGAN et al. (2012) analyzed the use of dendrometers to establish irrigation management in tangerine. These authors found that it is necessary to emphasize the adequacy of maximum trunk contraction measurements, aiming to establish a reference baseline for irrigation schedule in tangerines, due to its linear response and good correlation with temperature.

SOUZA (2009) used dendrometric measurements as indicators of irrigation management in coffee culture, when analyzing two treatments: one was always irrigated, and the other did not received irrigation up to a certain limit of leaf water potential, which then received water. This author found that the daily maximum amplitude of the stem was correlated with weather conditions and plant transpiration, satisfactorily reflecting the variation of leaf water potential. In addition, the daily maximum stem amplitude early indicated water stress in young coffee plants, in comparison to measurements of leaf water potential. 
CONEJERO et al. (2010) studied peach tree, evaluating its maximum daily trunk contraction during fruit growing period and 20 days after harvest, in fully irrigated condition. The authors found that, although crop production with high burden of fruits does not affect the condition of the water plant; the maximum daily trunk contraction has been increased. The authors concluded that reference values of maximum daily trunk contraction must be obtained in relation to climatic variables (average daily air temperature, vapor pressure deficit and reference evapotranspiration of crop) and at a certain level of crop production. The results obtained by PUERTO et al. (2013) indicate that the index from the maximum trunk contraction measures is an appropriate parameter for irrigation management during the vegetative period. The greater or lesser accuracy of index adjustments depends on the phenological stage and the intensity of plant stress.

Publications discussing the use of trunk diameter variations as water stress indicators were reviewed by FERNÁNDEZ \& CUEVAS (2010) and ORTUNÕ et al. (2010). These reviews showed that trunk diameter variation records depend not only on the scarcity of water, but also on seasonal growth patterns, fruit burden, age and size of the plant, among other factors, that limit the usefulness of trunk diameter variations indices as indicators of water stress.

BONET et al. (2010) evaluated the efficiency of use of dendrometers in plum, as an indicator for irrigation management, using the concept of signal strength. The results showed that the technique did not always provide satisfactory irrigation schedules, possibly due to temporal changes in trunk contractions of the reference used to calculate signal strength. The authors point out as a difficulty in the use of dendrometers, even with the best of current knowledge, the absence $f$ hardware and software packages that can offer the possibility of rural producers easily use and understand the data generated by this technique. This fact is due to the high degree of complexity of data generated and its difficult interpretation.

Zim probe: a new tool for irrigation management Variations of leaf water potential before sunrise and at noon can be obtained through a newly developed probe, which provides information about relative changes in leaf turgor pressure (ZIMMERMANN et al., 2008), known commercially as ZIM-probe.

RODRIGUEZ-DOMINGUEZ et al. (2012) stated that once turgor pressure is related to leaf water potential and xylem pressure, respectively, one of the most important driving forces for sap flow can be monitored longer. Thus, multiplying the stored values obtained by the probe and the sap flow, it is possible to study the transport of water over a time interval,by measuring, from a single leaf, water status of the entire tree. MEINZER et al. (2001), in their review about water transport in trees, analyzed new perspectives and new ideas, as well as some controversy. According to them, the data obtained by the new probe have shown that changes in the irrigation regime and microclimate can be detected by the methodology, showing great sensitivity to variations.

The sending of signals from the probe through a mobile network to a server on the internet, in which data is stored and displayed in the form of graphs or tables in real time, is a great advantage of the system for monitoring leaf water status. ZIMMERMANN et al. (2013) mentioned that the new probe has become an important tool in plant physiology, molecular biology and ecology, being also very important for irrigation management evolution. This occur because it is a robust, easy-touse method, through which producers can receive the information about the water needs of their plants by wireless telemetry, mobile network and internet, and can thus precisely adjust both the moment of irrigation and the amount of water to be applied.

WESTHOFF et al. (2009) state that the probe potential for measuring changes in leaf turgor pressure, for long periods, is demonstrated by measurements in several crops under different climate and irrigation conditions. These authors concluded that ZIM-probe can be used as an early warning system of water stress beginning and that the probe gives way to a more appropriate form of measuring crop water demand, both in the field and in the greenhouse.

The probe consists of a miniaturized pressure sensor integrated to a magnetized support, which is positioned on an intact piece of leaf in the plant (ZIMMERMANN et al., 2009). The imams apply steady pressure for fixation on the leaf, in a way that the pressure sensors are able to detect relative changes in turgidity (BRAMLEY et al., 2013).

ZIMMERMANN et al. (2009) showed that the leaf turgor pressure probe may accompany the diurnal changes, as well as fluctuations in turgor pressure in large leaves such as banana tree. The curves found in this study demonstrated the loss of turgor pressure around noon, the occurrence of turgor pressure oscillations and time required for the 
recovery of turgor pressure in the afternoon. These indicators, according to the authors, are useful for the analysis of plant water status.

EHRENBERGER et al. (2012) studied water relations in oak trees, analyzing its dependence on microclimate and soil moisture. These authors used dendrometers and the sensor, among other equipment, to measure variations in leaf turgor pressure. This study demonstrated that automated dendrometers and ZIM-probe are easy-to-use equipment and tools that operate on a continuous basis for the study of the water relations of trees, with great precision and high temporal resolution. Measurements using this equipment were able to reveal not only the dependence of stem water content and leaf turgor, in short and long term, on the fluctuations in microclimatic variables and soil moisture; but also provided information on the water movement in stems and leaves. FERNÁNDEZ et al. (2011b) used the leaf turgor pressure probe (ZIMprobe) as an indicator of water stress in olive trees. These authors concluded that the probe and the data transfer system are an accurate and robust technology, which is able to continuously monitor plantwater conditions, under field conditions, throughout different irrigation managements. This real-time information is beneficial to irrigation management in commercial orchards, in which the efficient water stress control is necessary for applying controlled water deficits.

RODRIGUEZ-DOMINGUEZ et al. (2012) evaluated concomitant measurements of sap flow and leaf turgor pressure using the ZIM-probe, in olive plants, analyzing diverse irrigation managements with controlled water deficit. Curves from turgor pressure variation managed to clearly define the limits to irrigation implementation. BRAMLEY et al. (2013) used the ZIM-probe to monitor the water status of wheat. These authors observed that the drying and wetting cycles have been identified by the methodology.

The records of leaf turgor potential, using the recently development ZIM probes, have been shown as useful for monitoring water stress in olive trees (FERNANDEZ et al., 2011b) and in other cultures. However, this methodology has limitations at certain values of water stress that must be analyzed, in addition to issues related to purchase and maintenance costs, in order to achieve the best use of the technique.

\section{CONCLUSION}

The analyzed methodologies present several technological challenges, in order to be satisfactorily presented to the end user. The upcoming research should study these tools to elaborate technical indices which will allow it simplification, both from the instrumental point of view and for the interpretation of results. There are several open issues, such as: what are the appropriate criteria to elect a reference plant? How many plants must be monitored per area? Which indexes would be suitable for the cultivation of interest? What are the main factors responsible for the measurements variations? And still, what are the water stress limits in which the values generated are reliable? All these questions must be answered by the research, so that such promising tools can be used, not only in trials, but also in the field, for the adequate monitoring of crops.

\section{ACKNOWLEDGEMENTS}

The Fundação de Amparo à Pesquisa do Estado do Rio de Janeiro (FAPERJ), Coordenação de Aperfeiçoamento de Pessoal de Nível Superior (CAPES) and Conselho Nacional de Desenvolvimento Científico e Tecnológico (CNPq) for the financial support.

\section{REFERENCES}

ALLEN, R.G. et al. Crop evapotranspiration-Guidelines for Computing Crop Water Requirements. In: FAO. Irrigation and drainage. Rome, 1998. p.56.

BONET, L. et al. Soil capacitance sensors and stem dendrometers Useful tools for irrigation scheduling of commercial orchards. Spanish Journal of Agricultural Research, v.8, n.2, p.5265, 2010. Available from: <http://revistas.inia.es/index.php/ sjar/article/viewFile/1348/1302>. Accessed: Apr. 01, 2014. doi:10.5424/sjar/201008S2-1348.

BRAMLEY, H. et al. Non-invasive pressure probes magnetically clamped to leaves to monitor the water status of wheat. Plant and Soil, v.369, p.257-268, 2013. Available from: $<$ http://www. plantstress.com/methods/ZIM\%20method\%20in\%20wheat.pdf>. Accessed: Apr. 01, 2014. doi:10.1007/s11104-012-1568-x.

BURGUESS, S.S.O.E.; DAWSON, T.E. Using branch and basa trunk sapflow measurements to estimate whole-plant water capacitance: a caution. Plant and Soil, v.305, p.5-13, 2008. Available from: $<$ http://download.springer.com/static/pdf/218/art $\%$ 253A10.1007\%252Fs11104-007-9378-2.pdf?auth66=1396628257 aa963bcaa40bff5880db916a86bc3422\&ext=.pdf $>$. Accessed: Apr 01, 2014. doi:10.1007/s11104-007-9378-2

ČERMÁRK, J. et al. Sap flow measurements with some thermodynamic methods, flow integration within trees and scaling up from sample trees to entire forest stands. Trees, v.18, p.529546, 2004.Available from: <http://download.springer.com/static/ pdf/586/art\%253A10.1007\%252Fs00468-004-0339-6.pdf?auth 66=1396629028_250227c891982848406a638e88112610\&ext=. pdf>. Accessed: Apr. 01, 2014. doi:10.1007/s00468-004-0339-6.

CONEJERO, W. et al. Influence of crop load on maximum daily trunk shrinkage reference equations for irrigation scheduling of early maturing peach trees. Agricultural Water Management,

Ciência Rural, v.45, n.5, mai, 2015. 
v.97, p.333-338, 2010. Available from: <http://ac.els-cdn.com/ S0378377409002935/1-s2.0-S0378377409002935-main.pdf? tid=9174c164-ba84-11e3-b753-00000aacb35d\&acdnat $=139645 \overline{6}$ 609_5ebd60e6a600dbcf5818dc74d98ca40d>. Accessed: Apr. 01, 2014. doi:10.1016/j.agwat.2009.10.003.

EHRENBERGER, W. et al. Leaf patch clamp pressure probe measurements on olive leaves in a nearly turgorless state. Plant Biology, v.14, p.666-674, 2012. Available from: <http:// onlinelibrary.wiley.com/doi/10.1111/j.1438-8677.2011.00545.x/ pdf $>$. Accessed: Apr. 01, 2014. doi: 10.1111/j.14388677.2011.00545.x

FERNÁNDEZ, J.E. et al.Use of maximum trunk diameter measurements to detect water stress in mature "Arbequina" olive trees under deficit irrigation. Agricultural Water Management, v.98, p.1813-1821, 2011a. Available from: <http://ac.els-cdn.com/ S0378377411001466/1-s2.0-S0378377411001466-main.pdf? tid=a3b664f2-ba86-11e3-a066-00000aab0f6c\&acdnat $=1396457498$ e466bfab7a077d3adadce82c67379e75^>. Accessed: Apr. 01, 2014. doi:10.1016/j.agwat.2011.06.011

FERNÁNDEZ, J.E. et al.Online-monitoring of tree water stress in a hedgerow olive orchard using the leaf patch clamp pressure probe. Agricultural Water Management, v.100, p.25-35, 2011b. Available from: $<$ http://www.sciencedirect.com/science/article/pii/ S0378377411002228\#>. Accessed: Apr. 01, 2014. doi:10.1016/j. agwat.2011.08.015.

FERNANDEZ, J.E.; CUEVAS, M.V. Irrigation scheduling from stem diameter variations: a review. Agricultural and Forest Meteorology, v.150, p.135-151, 2010. Available from: <http:// ac.els-cdn.com/S0168192309002718/1-s2.0-S0168192309002718main.pdf?_tid=f2cd8ef8-ba86-11e3-a08a-00000aab0f02\&acdnat= 1396457631 7ed65e4edce3b0b27506a9b4a3d0a7c4>. Accessed: Apr. 01, 2014.doi: 10.1016/j.agrformet.2009.11.006.

FERNÁNDEZ, J.E. The use of sap flow measurements for scheduling irrigation in olive, apple and Asian pear trees and in grapevines. Plant and Soil, v.305, p.91-104, 2008a. Available from: $<$ http://www.researchgate.net/publication/225845193_The_use of_sap_flow_measurements_for_scheduling_irrigation_in_olive apple and Asian pear_trees_and in grapevines $>$. Accessed: Apr. 01, 2014. doi: $10.1007 / \mathrm{s} 1110 \overline{4}-00 \overline{7}-9348-8$.

FERNÁNDEZ, J.E. et al.Design and testing of an automatic irrigation controller for fruit tree orchards, based on sap flow measurements. Australian Journal Agriculture Resourch. v.59, p.589-598, 2008b. Available from: <http://www.publish.csiro. au/paper/AR07312.htm>. Accessed: Apr. 01, 2014. doi: 10.1071/ AR07312.

FERNÁNDEZ, J.E. The use of sapflow measurements for scheduling irrigation in olive, apple and Asian pear trees and in grapevines. Plant and Soil, v.8, p.1104-1107, 2007. Available from: $<$ http://www.irriqual.eu/Documentos/Fern\%C3\%A 1 ndez $\% 20$ et\%20al\%20SAP\%20FLOW.pdf>. Accessed: Apr. 01, 2014. doi:10.1007/s11104-007-9348-8.

FERNÁNDEZ, J.E. et al.Heat-pulse measurements of sapflow in olives for automating irrigation: tests, root flow, and diagnostics of water stress. Agricultural Water Management, v.51, p.99-123, 2001.Available from: <http://www.sciencedirect.com/science/ article/pii/S0378377401001196>. Accessed: Apr. 01, 2014. doi: 10.1016/S0378-3774(01)00119-6.
GOLDHAMER, D.A.; FERERES, E. Irrigations cheduling protocols using continuosly recorded trunk diameter measurements. Irrigation Science, v.20, p.115-125, 2001. Available from: $<\mathrm{http}: / /$ www.irnase.csic.es/users/jefer/Articulos $\% 20$ en $\% 20$ papel $\% 20$ JE/FLUJO\%20DE\%20SAVIA\%20Y\%20DENDROMETRIA/ goldhamer2001.pdf $>$. Accessed: Apr. 01, 2014. doi:10.1007/ s002710000034.

GOLDHAMER, D.A. et al. Sensitivity of continuous and discrete plant and soil water status monitoring in peach trees subjected to déficit irrigation. Journal of the American Society for Horticultural Science, v.124, n.4, p.437-444, 1999. Available from: <http://journal.ashspublications.org/ content/124/4/437.full.pdf>. Accessed: Apr. 01, 2014.

GRANIER, A. Une nouvelle méthode pour la mesure du flux de sève brute dans le tronc des arbres. Ann Sci Forest, v.42, n.2, p.193-200, 1985.

LURBE, C.B. Regulated deficit irrigation in citrus: agronomic response and water stress indicators. 2013. 176f.(Thesis) Universidad Politécnica de Valencia, Escuela Técnica Superior de Ingenieros Agrónomos, Valência.

MARIN, F.R. et al. Fluxo de seiva pelo método do balanço de calor: base teórica, qualidade das medidas e aspectos práticos. Bragantia, v.67, p.1-14, 2008. Available from: <http://www.scielo.br/scielo. php?pid $=$ S0006-87052008000100001\&script $=$ sci arttext $>$. Accessed:Apr. 01, 2014.doi: 10.1590/S0006-87052008000100001.

MEINZER, F.C. et al. Water transport in trees: current perspectives, new insights and some controversies. Environmental and Experimental Botany, v.45, p.239-262, 2001. Available from: $\quad<\mathrm{http}$ ///research.eeescience.utoledo.edu/lees/papers_pdf/ Meinzer 2001 EnvExpBot.pdf>. Accessed: Apr. 01, 2014.

NAOR, A. Irrigation scheduling and evaluation of tree water status in deciduous orchards. Horticultural Reviews, v.32, p.111-165, 2006. Available from: <http://onlinelibrary.wiley.com/ doi/10.1002/9780470767986.ch3/summary>. Accessed: Apr. 01, 2014. doi: 10.1002/9780470767986.ch3.

NAOR, A.; COHEN, S. Sensitivity and variability of maximum trunk shrinkage, midday stem water potential, and transpiration rate in response to with holding irrigation from fiel-grown apple trees. Hortscience. v.38, n.4, p.547-551, 2003. Available from: $<$ http://hortsci.ashspublications.org/content/38/4/547.full.pdf $>$. Acessed: Sep. 01, 2013.

ORTUÑO, M.F. Could trunk diameter sensors be used in woody crops for irrigation scheduling? A review of current knowledge and future perspectives. Agricultural Water Management, v.97, p.111, 2010. Available from: <http://www.sciencedirect.com/science/ article/pii/S0378377409002753\#>. Accessed: Apr. 01, 2014. doi:10.1016/j.agwat.2009.09.008.

ORTUÑO, M.F. et al. Stem and leaf water potentials, gases exchange, sapflow, and trunk diameter fluctuations for detecting water stress in lemon trees. Trees, v.20, p.1-8, 2006. Available from: <http://link.springer.com/article/10.1007\%2 Fs00468-005-0004-8>. Accessed: Apr.01, 2014. doi:10.1007/ s00468-005-0004-8

PAGÁN, E. et al. Suitability of trunk diameter reference lines for irrigation scheduling with saline water in late mandarin trees with different crop load. Agricultural Water Management,

Ciência Rural, v.45, n.5, mai, 2015. 
v.111, n.11-19, 2012. Available from: <http://journals.ohiolink. edu/ejc/article.cgi?issn $=03783774 \&$ issue $=v 111$ inone $c \&$ artic le $=11 \_$sotdrlmtwdcl $>$. Accessed: Apr. 01, 2014. doi: 10.1016/j. agwat.2012.04.008.

PIMENTEL, J.S. et al. Estimativa da transpiração em cafeeiros utilizando-se sensores de dissipação térmica. Revista Brasileira Engenharia Agrícola Ambiental, v.14, n.2, p.187-195, 2010. Available from: $<\mathrm{http}: / /$ www.scielo.br/pdf/rbeaa/v14n2/v14n02a10. pdf $>$. Accessed: Apr. 01, 2014.

PONS, P.J. Sap flow technique as a tool for irrigation schedule in grapevines: Control of the plant physiological status.In: LÓPEZFRAN $\cos$ A. (ed.). Drought management: scientific and technological innovations. Zaragoza: CIHEAM, 2008. p.375-378

PUERTO, P. Remote management of deficit irrigation in almond trees based on maximum daily trunk shrinkage. Water relations and yield. Agricultural Water Management, v.126, p.33-45, 2013 Available from: <http://ac.els-cdn.com/S0378377413001108/1 s2.0-S0378377413001108-main.pdf?_tid=27bfd8c8ba $8 \mathrm{c}-11$ e 3 -a603-00000aacb35e\&acdnat $=1396459867$ f58bf581931665fda3de0f176be04ba9>. Accessed: Apr. 01, 2014. doi: 10.1016/j.agwat.2013.04.013.

RAMOS, A.F.; SANTOS, F.L. Water use, transpiration, and crop coefficients for olives (cv. 'Cordovil'), grown in orchards in Southern Portugal. Soil and Water, v.102, p.321333, 2009. Available from: <https://www.rdpc.uevora.pt/ bitstream/10174/6053/1/biosEng_ramos_water\%20use, $\% 20$ transpiration, $\% 20$ crop\%20coeficients.pdf $>$. Accessed: Apr. 01, 2014. doi: 10.1016/j.biosystemseng.2008.12.006.

REMORINI, D.; MASSAI, R. Comparison of water status indicators for young peach trees. Irrigation Science, v.22, p.39-46, 2003. Available from: <http://www.researchgate.net/profile/Rossano Massai/publication/225172862 Comparison of water status indicators for young peach trees/file/9c96052298e $8 \mathrm{fe} 40 \mathrm{e} 7$. pdf >. Accessed: Apr. 01, 2014. doi: 10.1007/s00271-003-0068-4.

RODRIGUEZ-DOMINGUEZ, C.M. et al. Concomitant measurements of stem sap flow and leaf turgor pressure in olive trees using the leaf patch clamp pressure probe. Agricultural Water Management, v.114, p.50-58, 2012. Available from: <http:/ www.researchgate.net/publication/257199665_Concomitant measurements of stem sap flow and leaf turgor pressure in_olive_trees_using_the_leaf_patch_clamp_pressure_probe/ file/5046352a5d79d3f5ae.pdf $>$. Accessed: Apr. 01, 2014. doi: 10.1016/j.agwat.2012.07.007

ROJAS, J.S.D.; ANGELOCCI, L.R. Desempenho do dendrômetro de precisão na medida de deslocamento radial do caule de lima ácida "Tahiti" em resposta às diferentes condições ambientais. In:
XI Congresso Brasileiro de Meteorologia, 2000, Rio de Janeiro. Anais... XI Congresso Brasileiro de Meteorologia. Rio de Janeiro: Associação Brasileira de Meteorologia, 2000.

ROJAS, J.S.D. et al. Desempenho do método de dissipação térmica na medida do fluxo de seiva em seringueira. Engenharia Agrícola, v.26, n.3, p.722-729, 2006. Available from: <http://www.scielo.br/ scielo.php?script=sci_arttext\&pid=S0100-69162006000300008 $>$. Accessed:Apr. 01,2014. doi: 10.1590/S0100-69162006000300008.

SANTOS, A.O. et al. Determinação do fluxo de seiva em videira através da técnica do pulso de calor. Revista Brasileira de Agrometeorologia, v. 13, n.2, p.262-272, 2005.Available from: $<$ http://hortibrasil.org.br/jnw/images/stories/Uva/u.200.pdf . Accessed: Apr. 01, 2014.

SILVA, M.G. Desenvolvimento de sensor de fluxo de seiva e de coeficiente indicador de estresse hídrico para plantas de cafeeiro arábica. 2008. 114f. Tese (Doutorado em Produção Vegetal) - Universidade Estadual do Norte Fluminense, RJ.

SOUZA, L.F. Utilização da variação dendrométrica como indicador para o manejo da irrigação de plantas de café. 2009. 65f. Dissertação (Mestrado em Produção Vegetal) - Universidade Estadual do Norte Fluminense Darcy Ribeiro, RJ.

WESTHOFF, M. et al. A non-invasive probe for online-monitoring of turgor pressure changes under field conditions. Plant Biology, v.11, p.701-712, 2009. Available from: <http://onlinelibrary.wiley. com/doi/10.1111/j.1438-8677.2008.00170.x/abstract>. Accessed: Apr. 01, 2014. doi: 10.1111/j.1438-8677.2008.00170.x.

ZIMMERMANN, U. et al. A non-invasive plant-based probe for continuous monitoring of water stress in real time: a new tool for irrigation scheduling and deeper insight into drought and salinity stress physiology. Theoretical and Experimental Plant Physiology, v.25, n.1, p.2-11, 2013. Available from: <http://www. scielo.br/pdf/txpp/v25n1/a02.pdf >. Accessed: Apr. 01, 2014.

ZIMMERMANN, U. et al. Effects of environmental parameters and irrigation on the turgor pressure of banana plants measured using the non-invasive, online monitoring leaf patch clamp pressure probe. Plant Biology, v.12, p.424-436, 2009. Available from: <http:// onlinelibrary.wiley.com/doi/10.1111/j.1438-8677.2009.00235.x/ abstract>. Accessed: Apr. 01, 2014. doi: 10.1111/j.14388677.2009.00235.x.

ZIMMERMANN, D. et al. A novel, non-invasive, onlinemonitoring, versatile and easy plant-based probe for measuring leaf water status. Journal of Experimental Botany, v. 59 , p.3157-3167, 2008. Available from: <http://www.ncbi.nlm.nih. gov/pmc/articles/PMC2504341/>. Accessed: Apr. 01, 2014. doi: $10.1093 / \mathrm{jxb} / \mathrm{ern} 171$. 


\section{ERRATUM}

Artigo "Advanced techniques using the plant as indicator of irrigation management" publicado no fascículo v45n5 de maio da Ciência Rural páginas 821-827 sem a inclusão de duas citações e correspondentes referências, onde se lia:

"In the case that the irrigated plant is considered in isolation, such as in an orchard, for example, the biggest problem is to determine the volume of water to be applied for each time period and the moment it should be applied. This is due to the little knowledge about the amount of water used by a plant during its transpiration with the soil in excellent water conditions."

"Plant indicators have been used, primarily in research, as methods for estimating water stress; and their practical applications in irrigation management are still being developed."

leia-se:

"In the case that the irrigated plant is considered in isolation, such as in an orchard, for example, the biggest problem is to determine the volume of water to be applied (ROJAS and ANGELOCCI, 2000) for each time period and the moment it should be applied. This is due to the little knowledge about the amount of water used by a plant during its transpiration with the soil in excellent water conditions (ROJAS and ANGELOCCI, 2000)."

"Plant indicators have been used, primarily in research, as methods for estimating water stress; and their practical applications in irrigation management are still being developed (NAOR and COHEN, 2003).”

NAOR, A.; COHEN, S. Sensitivity and variability of maximum trunk shrinkage, midday stem water potential, and transpiration rate in response to with holding irrigation from fiel-grown apple trees. Hortscience. v.38, n.4, p.547-551, 2003. Available from: $<$ http://hortsci.ashspublications. org/content/38/4/547.full.pdf>. Acessed: Sep. 01, 2013.

ROJAS, J.S.D.; ANGELOCCI, L.R. Desempenho do dendrômetro de precisão na medida de deslocamento radial do caule de lima ácida "Tahiti” em resposta às diferentes condições ambientais. In: XI Congresso Brasileiro de Meteorologia, 2000, Rio de Janeiro. Anais... XI Congresso Brasileiro de Meteorologia. Rio de Janeiro: Associação Brasileira de Meteorologia, 2000.

Para a versão correta, acesse:

http://www.scielo.br/pdf/cr/v45n5/0103-8478-cr-45-05-00821.pdf 